\title{
A Life Triumphantly Well Written: Producing the Hawke Legacy, 1979-2019
}

Joshua Black

The Australian National University

Abstract: In recent decades, there has been an increase in scholarly attention to biographical political writing in Australian national culture. In particular, there have been several biographies and televisual 'biopics' about Australia's 23rd prime minister, Robert James Lee Hawke. In this article, I argue that Hawke demonstrated a proclivity for managing or contributing to historiographical projects that were intended to build or buttress his personal and political legacy. That legacy has been one in which Hawke is considered 'legendary', and his government potentially the best that Australia has had. In addition to archival and oral research, I conduct a close reading of several major biographical and autobiographical texts concerning Hawke. I conclude that Hawke's legacy-building initiatives occurred in three distinct phases: a foundational myth-making phase, a post-prime ministerial reactionary phase and a twenty-first-century ascendant phase. Throughout each, Hawke was supported by meaningful and collaborative partnerships with biographer and partner Blanche d'Alpuget, private secretary Jill Saunders, loyal former colleagues, close friends and project-specific co-creators. This research acts as a reminder that politicians have historically had a vested interest in legacy building, and that audiences must be encouraged to critique rather than accept by default the laudatory narratives that politicians generate about themselves.

The scent of Great Man history was in the air at the memorial service to Australia's 23rd prime minister at the Sydney Opera House on 14 June 2019. ${ }^{1}$ Friends, loved ones and former colleagues, mostly Australian Labor Party (ALP) figures, rose to offer their reflections on Robert

1 The author thanks Professor Melanie Nolan, Professor Frank Bongiorno and Jessica Urwin for their comments and reflections on this paper, as well as staff at the National Library of Australia for granting permission to quote letters from Blanche d'Alpuget's personal papers. This research is supported by an Australian Government Research Training Program Scholarship (AGRTP). 
James Lee Hawke, many of which were both idolatrous and irreverent. Though some speakers, such as Paul Keating, one of the five former prime ministers in the house, were politely reserved, others shared anecdotes and drew conclusions that reflected the popular image of the man and his character. For Kim Beazley, a Hawke protégé and former Labor leader, 'Bob exemplified Bagehot's view of great prime ministers as men of commonplace opinions and uncommon administrative abilities'. For Bill Kelty, former Australian Council of Trade Unions (ACTU) secretary and Hawke confidant, Hawke was a 'person who raised the aspirations of this nation'. Craig Emerson, former Hawke adviser and Gillard government minister, told the lighthearted story of having once forgotten to put a bet on a successful horse on Hawke's behalf, the purpose of the gag being 'to celebrate Bob's life and the wonderful, inspiring, decent human being he was'. For Blanche d'Alpuget, Hawke's widow and biographer, the memorial was 'the transition from the grief of loss to the celebration of a life triumphantly well lived'. ${ }^{2}$

There were a range of narratives on show at Hawke's memorial, most of them laudatory, some of them already in print. Many of the statements and passages were derived from d'Alpuget's two major biographies of her husband, Hawke's own memoirs, the multiple tele-documentaries or films about Hawke and a raft of other favourable historical accounts of his life and work. Indeed, I argue that Hawke's legacy building was a deliberate and long-term project spanning four decades and involving three main phases: a foundational phase in the 1980s, a reactive phase in the 1990 s and an ascendant phase in the new millennium.

Though a large variety of texts could be considered influential in terms of Hawke's reputation-including key speeches and interviews-this paper deals exclusively with published literary and visual products that can be considered major historiographical undertakings. That there are so many of these to begin with testifies to the sustained efforts of publishers, producers and the former prime minister himself to curate and massage his

2 Kim Beazley, 'Bob Hawke Governed with His Cabinet, Kim Beazley Tells Memorial Service', Sydney Morning Herald, 14 June 2019, accessed 18 July 2019, bit.ly/2XTDZ88; Bill Kelty, 'Bill Kelty Tells Memorial Service How Bob Hawke Fixed the Economy', Sydney Morning Herald, 14 June 2019, accessed 18 July 2019, bit.ly/2O2QVJd; Craig Emerson quoted in ABC, 'Hawke Memorial: Craig Emerson Gives Tribute to Bob Hawke with an Anecdote', YouTube, accessed 17 July 2019, www.youtube.com/watch?v=6iYkg71z3Pk; Blanche d'Alpuget quoted in ABC, 'Hawke Memorial: Hawke's Family Speaks on His Life Well Lived', YouTube, accessed 18 July 2019, www.youtube.com/ watch? $=1$ MAmsPgtH1w. 
reputation for posterity. In analysing these literary and filmic productions, I draw on a range of sources available from the contemporaneous public record, such as press reports, critical reviews, published extracts, opinion polling and sales figures. The resulting narrative is a revealing example of a politician dictating to posterity what has become, at least for the moment, the dominant historiographical narrative about himself.

\section{The Foundational Phase, 1979-84}

By 1979 Hawke was already one of the most renowned and controversial public figures in the nation. The popular president of the ACTU was regularly in the news, had developed a prolific national profile and was often touted as a future prime minister. Other biographers, namely John Hurst and Robert Pullan, had already begun to evaluate Hawke's career and contribution to the labour movement. ${ }^{3}$ The development of what could be termed the 'Hawke cult of personality' was gradual, but in the early 1980s one project went further than any other to capture the essence of Hawke's character. Robert J. Hawke was written by biographer and former lover Blanche d'Alpuget, and it is with this work that the pair began what would ultimately become a joint mission both to record and create Hawke's legacy over multiple decades. The idea for a Hawke biography developed out of another project d'Alpuget was researching, a biography of Sir Richard Kirby, president of the Australian Conciliation and Arbitration Commission, which she published in 1979. Derek Rielly records that Hawke 'had appeared innumerable times before Kirby' and, therefore, d'Alpuget decided to pursue him for an interview. ${ }^{4}$ Having already commenced an affair prior to the Kirby book, the pair broke up, but subsequently reunited to create a biography of Hawke that would yield historical value and political impact. The research consisted of scores of interviews with Hawke and his family, friends and associates, and archival material from the National and Parliamentary libraries. Several people read the manuscript prior to publication, including d'Alpuget's editor Elizabeth Douglas, her mentor Peter Ryan, who was director of Melbourne University Press, a number of political psychologists

3 Robyn Ferrell, 'Entertainer's Biography of Bob Hawke', Canberra Times, 28 July 1982, 16. For more, see John Hurst, Hawke: The Definitive Biography (Sydney: Angus \& Robertson, 1979); Robert Pullan, Bob Hawke: A Portrait (Sydney: Methuen Australia, 1980).

4 Bob Hawke and Derek Rielly, Wednesdays with Bob (Sydney: Pan Macmillan, 2018 [2017]), 254. 
in Melbourne and Hawke himself.5 Notwithstanding the supposedly 'warts-and-all' nature of the study, Hawke's editorial involvement reflected that the likely political consequences of the book could substantially effect his subsequent career. ${ }^{6}$

Robert J. Hawke reveals some of the depths and hidden complexities of Hawke's personality. Readers were told that Hawke's mother, Edith, intended on him being Elizabeth Hawke, a daughter, and that Edith reminded her son of her disappointment for some years. ${ }^{7}$ As a result, writes d'Alpuget, a 'defiant masculinity was a central aspect of Hawke's personality', which led to 'displays of swashbuckling virility' and, when pushed to excess, 'womanising. ${ }^{8}$ She describes Hawke's as a 'double life':

On one side there was the gregarious student leader, already sexually experienced, a beer-garden king who when indignant would throw punches. On the other there was the minister's son who abhorred violence, who went to church on Sundays.?

Even today, the reader may find it difficult to reconcile the two faces of the Hawke personality, though many revel in his combination of 'larrikin' and 'leader' qualities.

The biography is also effective in outlining the extent to which Hawke's path to the nation's parliament was long and laden with both opportunities and setbacks. Hawke's life-threatening motorcycle accident at age 17 is given as an inspiring date with destiny: having survived, 'I decided I was going to live my life to my utmost ability'. ${ }^{10}$ His tertiary education journey is neatly mapped from his law degree and economics major at the University of Western Australia, to his Rhodes Scholarship at Oxford, to his incomplete doctorate at The Australian National University (ANU). ${ }^{11}$ He is described at various stages of the character progression as a 'larrikin' and a 'Wild Colonial Boy', and is shown to have indulged in drunken escapades at both Oxford and ANU. ${ }^{12}$ In his first appearance at the

5 Blanche d'Alpuget, Robert J. Hawke: A Biography (Port Melbourne: Mandarin, 1994 [1982]), viii-ix.

6 d'Alpuget, Robert J. Hawke, xi.

7 d'Alpuget, Robert J. Hawke, 6.

8 d'Alpuget, Robert J. Hawke, 6.

9 d'Alpuget, Robert J. Hawke, 39.

10 Hawke quoted in d'Alpuget, Robert J. Hawke, 32.

11 d'Alpuget, Robert J. Hawke, 51.

12 Wheeldon quoted in d'Alpuget, Robert J. Hawke, 24, 59. For Hawke's Oxford misdemeanours, see pages 59-60; for his embarrassing episode at ANU, see page 66. 
ACTU, Hawke is portrayed as 'highly strung, restless in his gestures'. But, by 1961, Hawke is praised as 'a hero' of the union movement as a result of his advocacy for 'wages justice'. ${ }^{13}$

Fundamental to the construction of Hawke's image within Robert J. Hawke are a number of pivotal moments in his life. These include the death of his and first wife Hazel's infant son, Robert; Hawke's defeat at the 1963 election as the ALP candidate for Corio; and his shattering defeat in the 1965 wage case. ${ }^{14}$ By 1970, Hawke was president of the ACTU and, in 1971, he was named 'Victorian Father of the Year', which even the recipient acknowledged must have been an affront to his wife. ${ }^{15}$ The remainder of the book narrates Hawke's years as dual president of both the ACTU and the ALP, a role that brought him into direct conflict with Prime Minister Gough Whitlam and that made Labor appear 'a two-headed calf'. Many of the biographical storylines followed here are valuable insofar as they have been sidelined in the contemporary Hawke mythology. The book records Hawke's experiences in 1970s Arab-Israeli conflict management, encapsulates the 'blur' of the Whitlam dismissal, explains the left-wing 'Stop Hawke' campaign in the late 1970s, and recounts the politically and personally vexed debate over uranium mining. ${ }^{16}$ Robert J. Hawke even grapples with scenes of a suicidal Hawke traumatised by the difficulties of negotiating with the USSR over the Jewish refusenik question, showing the union leader in 'the weakest negotiating position he's ever been in'. ${ }^{17}$

D'Alpuget's work was intended not just as fodder for the historical record, but also as a political primer. In particular, the final chapters were intended to promote Hawke as a reformed man marching towards his prime ministerial destiny. On alcohol, he is quoted as saying, 'I knew what the minuses were, and I just had to admit them'. ${ }^{18}$ The closing pages follow Hawke's trajectory from the ACTU to the Labor frontbench, where leadership tension with Bill Hayden, ALP Opposition leader, became inevitable. It is clear that Hawke wanted to use this biography to position himself as the future Labor leader, a rejuvenated man ready to rejuvenate his country. The pressure he brought to bear on the manuscript is evident in the letters d'Alpuget sent to her editor, Elizabeth Douglas, in the later

13 d'Alpuget, Robert J. Hawke, 82, 99.

14 On the death of Robert James Hawke junior, see d'Alpuget, Robert J. Hawke, 100. For the 1963

election, see pages 102-09. For the 1965 wage judgement, see pages 119-22.

15 d'Alpuget, Robert J. Hawke, 197.

16 d'Alpuget, Robert J. Hawke, 243-44; Hawke quoted on pages 289, 303, 317.

17 Liebler quoted in d'Alpuget, Robert J. Hawke, 368.

18 Hawke quoted in d'Alpuget, Robert J. Hawke, 396. 
stages of the writing process. In late April, Blanche wrote, '[Hawke] wants more said about what a reformed character he became when he gave up the grog. ${ }^{19}$ Four days later, she wrote again to Douglas claiming that Hawke was 'unhappy about the last chapter', and that she would 'have to do a bit of re-writing on this, possibly in the final paragraph'. ${ }^{20}$ There is little doubt that, despite the professed desire for a warts-and-all biography, Hawke preferred that it maximise his leadership prospects in the immediate future.

In this period, of course, Hazel Hawke remained central to the effort to get her husband elected and to bolster his standing with the Australian electorate. Despite the fissures in their marriage, by 1980 Hazel remained pivotal to Hawke's ascendancy, partly because a divorce would have been electorally problematic. ${ }^{21}$ In the context of campaigns, she was 'loved by the women's magazines for the long-suffering way in which she stood by her husband'. ${ }^{22}$ Behind the scenes, she was also deeply involved in the efforts to frame Hawke's biography for the electorate. D'Alpuget's book begins with an acknowledgement of Hazel:

Her desire to protect [their children], and not to have re-published matters which have already appeared in the Press, has been a price worth paying for her help and unflinching frankness, both in giving information and in reading the manuscript for accuracy. ${ }^{23}$

Following Labor's victory, Hazel declared, 'I will commit myself to the job with responsibility'. ${ }^{24}$ At key moments in the life of the government, Hazel would honour this commitment, most obviously in September 1984 as the Hawkes were rocked by the revelation of their daughter Rosslyn's drug addiction. Speaking publicly about the personal crisis at the time, she said: 'It is very much a family process, and it just so happens that I am the spokesman. ${ }^{25}$ Further, she defended Hawke's public tears at a press conference earlier that month when asked about his family's

19 Letter from Blanche d'Alpuget to Elizabeth Douglas, 29 April 1982, National Library of Australia (NLA), MS 7348, Papers of Blanche d'Alpuget, [4].

20 Letter from Blanche d'Alpuget to Elizabeth Douglas, 3 May 1982, NLA, MS 7348, Papers of Blanche d'Alpuget, [4].

21 Patricia Edgar, 'Hazel Hawke Written Out in Biased History', Age, 21 July 2010, 13.

22 John Huxley, 'Political Wives Must Be Clean and Not Heard', Sydney Morning Herald, 2 October 1997, 11.

23 d'Alpuget, Robert J. Hawke, xi.

24 Hazel Hawke quoted in 'Hazel Hawke Intent on Staying Sane', Canberra Times, 7 March 1983, 11.

25 Hazel Hawke quoted in 'PM's Wife Tells of Daughter's Heroin Addiction', Canberra Times, 25 September 1984, 1. 
drug challenges. 'What matters is that you come back after the blow', she said, 'and he always has. ${ }^{26}$ Directly and indirectly, Hazel proved essential both to Hawke's political ambitions, and-in her capacity as family 'spokesman'- to his cult of personality as well. ${ }^{27}$

Though it is difficult to assess the impact of Robert J. Hawke on political circumstances in 1982, I agree with historian Christine Wallace's assessment that this biography constituted 'a political intervention to help Hawke' on the path to power. ${ }^{28}$ Richard Kirby launched the book on 5 October 1982 at Canberra's Lakeside Hotel alongside d'Alpuget and Hawke, who, just a few months earlier, had challenged for the leadership and lost. In his speech, Kirby said that Hawke would 'be proud to be a leader in the national team, even if the actual number one job eludes him. I personally hope it does not. ${ }^{29}$ The Canberra Times marked the release of the book with a highly partisan headline over a review by a former Labor deputy prime minister, Jim Cairns: 'Warts-and-all portrayal of a man who "could make a good PM". ${ }^{30}$ The commercial success of the biography, much speculated about before publication, became rapidly assured; claims circulated that the first 15,000-copy print run had sold out before the official launch date. ${ }^{31}$ According to d'Alpuget, Morry Schwartz's commercial capacities were essential for ensuring the book's success in both political and market terms:

It was his idea to make the cover black and white, because the eye is naturally drawn to white, so the book would stand out from others on the shelf ... [He] persuaded the most prestigious book shop in Melbourne, Hill of Content, to fill its entire window with nothing but the Hawke biography. ${ }^{32}$

26 'PM's Wife Tells of Daughter's Heroin Addiction', 1.

27 Hazel Hawke quoted in 'PM's Wife Tells of Daughter's Heroin Addiction', 1.

28 Christine Wallace, 'The Silken Cord: Contemporaneous Australian 20th Century Political Biography \& Its Meaning' (PhD diss., The Australian National University, 2015), 366.

29 Sir Richard Kirby, Launching Speech at the Lakeside Hotel, Canberra, 5 October 1982, National Archives of Australia (NAA): M4363/4.

30 Jim Cairns, 'Warts-and-All Portrayal of a Man Who "Could Make a Good PM"', Canberra Times, 5 October 1982, 2.

31 Alison Broinowski, 'Blanche d'Alpuget: Finding Challenge Irresistible', Australian Women's Weekly, 20 October 1982, 10.

32 Testimonial from d'Alpuget in Blanche d'Alpuget, 'Robert J. Hawke: A Biography', blanchedalpuget. com, 2019, accessed 2 December 2019, www.blanchedalpuget.com/index.php/en/books/robert-jhawke-a-biography (site discontinued). 
Commercial success begat the book's political acuity. By d'Alpuget's account, the book convinced John Button and Lionel Bowen, two critical members of the ALP National Executive and two critical votes in Caucus, that Hawke had 'the depth of experience necessary to become leader'. ${ }^{33}$ Of course, political manoeuvres rarely pan out according to grand design, but within four months, Hawke was the leader of the Australian Federal Parliamentary Labor Party, and within five was prime minister of Australia. ${ }^{34}$ At the very least, it is clear that the book was conducive to Hawke's ascension, and that this major contribution to the Hawke canon was an undisputed success.

More than simply framing Hawke's life in a dramatic historical narrative, d'Alpuget was careful to analyse critically Hawke's character in the tradition of the Melbourne school of psychobiography, which famously combined 'an historical narrative approach with political psychology'. ${ }^{35}$ She acknowledged Michael Epstein, Ross Martin, Angus McIntyre and Graham Little for their disciplinary influence on the manuscript, an influence that underscores many of the analytical passages about Hawke's character development. On his struggle against alcohol abuse, for instance, she writes:

The enemy was himself ... he had to smash up the old Bob Hawke and create a new one, stalked by the anxiety that if he succeeded it may be at the cost of his magic touch. ${ }^{36}$

With its emphasis on catalysts for character development and its subtle use of psychobiography, the book remains the definitive account of his pre-parliamentary career.

\section{The Reactive Phase, 1993-99}

In 1983 Hawke was the stuff of Australian legend. By 1993 that initial glamour had been displaced by cynicism. The Australian economy was groaning under the pressure of a recent recession, Hawke had abandoned the infamous 'secret' Kirribilli pact whereby he promised to vacate the

\footnotetext{
33 Hawke and Rielly, Wednesdays with Bob, 258.

34 Wallace, 'The Silken Cord', 392.

35 Kate White, 'Towards an Assessment of Australian Political Biography', Politics 16, no. 1 (1981):

134, doi.org/10.1080/00323268108401793.

36 d'Alpuget, Robert J. Hawke, 336.
} 
prime ministership for Keating, and the press were aware of Hawke reneging on the deal. In December 1991, Hawke became the first Labor prime minister to be removed by his own party, beaten by Keating 56-51 in a Caucus ballot. In the aftermath, Hawke and his peers began to proselytise their version of political history. Given the immediacy of the hurt and disappointment of 1991, this effort was more than a little coloured by a thirst for revenge and retribution. By d'Alpuget's account, this period was one of immense emotional turbulence for Hawke. ${ }^{37}$ From 1992 to 1994, Hawke sought to safeguard his legacy in the context of a more hostile political and media environment than he had previously faced. Another major disruption came with the breakdown of Hawke's marriage to Hazel in late 1994, and subsequent wedding to Blanche in 1995. As news of the Bob-Blanche affair surfaced, the Sydney Morning Herald predicted 'a further elevation in Hazel's standing ... and a corresponding further fall in Bob's' ${ }^{38}$ For some, the issue was not the love affair itself, but rather its performative nature. The new couple were allegedly paid $\$ 200,000$ for interviews with 60 Minutes and Woman's Day, with the latter publishing the now-infamous photos featuring 'towelling robes and glistening eyes'. ${ }^{39}$ All things considered, the 1990s saw the nadir of Hawke's public standing, a trajectory that began while Hawke was still in office, and long before the end of his first marriage.

Hawke and d'Alpuget's biographical narrative came under siege at the same time as the Hawke prime ministership began to collapse. In October 1991, as Hawke battled to keep the Keating forces at bay, Melbourne academic Stan Anson published a singularly unsympathetic psychoanalytical study of the prime minister, entitled Hawke: An Emotional Life. Journalists highlighted Anson's most Freudian portraits of Hawke, including 'the young Bob Hawke's narcissism, oedipal exaltation and castration anxiety'. ${ }^{40}$ The author claimed at the outset that Hawke was both 'narcissistic' and 'realistic', intensely ambitious and prone to 'grandiose fantasy'. ${ }^{41}$ His politics, in Anson's estimation, was fuelled by both 'knee-jerk utilitarianism and pragmatic acceptance' of the status quo. ${ }^{42}$ This was a far cry from the popular portrait of the

37 Blanche d'Alpuget, oral history interview with the author, Sydney, 21 February 2020.

38 Sue Williams, 'Hawke's Fine Romance', Sydney Morning Herald, 8 January 1995, 3.

39 Moira Rayner, 'Dignity in Short Supply For Bob and Blanche', Age, 13 February 1995, 10.

40 Jane Sullivan, 'Literary Battle for PM's Mind', Age, 12 October 1991.

41 Stan Anson, Hawke: An Emotional Life (Ringwood: McPhee Gribble, 1991), 3, 9.

42 Anson, Hawke An Emotional Life, 64. 
consensus-driven leader in love with the Australian people, though much of the book involved reinterpretations of d'Alpuget's earlier work. Upon the book's release, d'Alpuget was sufficiently outraged to write to Anson's publishers requesting that it be 'withdrawn in its present form'. ${ }^{43}$ When this was rejected, she took legal action against parent company Penguin Publishing, arguing that 'Anson's interpretation relied too heavily on her own biography'. ${ }^{44}$ Though a private settlement was later reached between all parties, ${ }^{45}$ the book nonetheless proved that 'sensitive revelations of the self could be turned into political bullets for one's enemies'. ${ }^{46}$

In response to changed political circumstances and Anson's assault on the 'legend', Hawke contributed to two major historiographical projects in the mid-1990s, neither of which commanded for him great respect among the public audience. The first was a much-anticipated tele-documentary entitled Labor in Power, screened over five weeks in mid-1993. The Australian Broadcasting Corporation (ABC) dedicated five hours of airtime to the project, which earned leading journalists Phillip Chubb and Sue Spencer a Gold Walkley media award. ${ }^{47}$ The series comprised archival news footage and interviews with 60 prominent members of government and their staff, former members of the public service and a few outside observers. ${ }^{48}$ The narrative arc spanned the rise of Hawke to the Labor leadership, right through to the Keating ascendancy and the quest to win the 1993 election, a period of both major reform and major personality clashes. Public commentary emphasised the 'astonishing frankness' of the interviewees, who made little or no secret of the animosities that brewed between Hawke and Keating supporters up to $1991 .^{49}$ Recorded before Labor's 1993 election victory, participants were candid on camera in the expectation that it would go to air as 'Labor's governmental obituary'. 50 Nielsen estimated that over 189,000 Australian households tuned into view the program..$^{51}$

43 Sullivan, 'Literary Battle'.

44 Judith Brett, 'Introduction', in Political Lives, ed. Judith Brett (Sydney: Allen \& Unwin, 1997), $\mathrm{ix}-\mathrm{x}$.

45 Caroline Wilson, 'Chapter Closes on Bitter Battle of the Publishers', Age, 1 March 1992, 2.

46 Wallace, 'The Silken Cord', 399.

47 “'Labor in Power” Takes Out Walkley', Canberra Times, 2 December 1993, 5.

48 Raymond Gill, “'Labor in Power”-A House Divided', Age, 3 June 1993, 1.

49 Tim Dodd, 'The Ministerial Wing-Where the Action Is', Australian Financial Review, 8 June 1993, 3; Gerard Henderson, 'The Laborious Business of Making History', Age, 8 June 1993, 18.

50 'Annus Mirabilis_-A Hard Slog for Labor', Age, 29 December 1993, 9.

51 Robin Oliver, 'Sports Scores Well For Nine', Sydney Morning Herald, 22 June 1993, 4. 
The series did nothing to further Hawke's reputation. Robert Manne wrote in the Age that 'Bob Hawke was the embodiment of political narcissism'. ${ }^{52}$ Raymond Gill described a 'sleazy portrait of a party in power'. ${ }^{53}$ According to the Sydney Morning Herald, in the battle for historical control, 'Keating won hands down'. ${ }^{54}$ Not all were as scathing of Hawke. Les Carlyon described the Labor government as 'a clutch of vain politicians ... playing a power game among themselves', but went on to say that the 'only participant who does not leave this impression is Bob Hawke. No wonder they kicked him out. ${ }^{55}$ Hawke was personally 'disappointed at the outcome' of the series, and perceived it as 'dishonest and biased'. ${ }^{56}$ Ultimately, Labor in Power made for engrossing television but did little to improve either the standing of the Keating Labor government or Bob Hawke's personal legacy.

The following year, Hawke published The Hawke Memoirs with the help of a cast of supporting actors. Hawke credits d'Alpuget with abandoning her own occupation 'to work as my editor as the deadline approached'. ${ }^{57}$ D'Alpuget recalled that her role was a purely literary, 'nuts and bolts' contribution to the book. ${ }^{58}$ Hawke's private secretary, Jill Saunders, was said to be 'heavily involved' in bringing the memoir to fruition, and several former staffers including Craig Emerson and Hugh White were named personally for their contributions. ${ }^{59}$ The publisher Louise Adler was thanked 'for her gentle but constant pressure and assistance'. ${ }^{60}$ Importantly, Hawke recognised the contribution of his researcher, Garry Sturgess, who laboured over much of the original manuscript. ${ }^{61}$ With the support of this team, Hawke intended that his book would explain 'the story of how and why' the ALP had 'made Australia a better place'. ${ }^{62}$ The result was a remarkably sanitised version of Hawke's history.

52 Robert Manne, 'The Real Villains', Age, 23 June 1993, 17.

53 Gill, “Labor in Power”, 1.

54 Mike Steketee, 'Rewriting the Hawke Ascendancy', Sydney Morning Herald, 13 July 1993, 10.

55 Les Carlyon, 'Carlyon Column', BRW, 25 June 1993, 16.

56 Garry Sturgess, oral history interview with the author, Manuka, Canberra, 7 February 2020;

Blanche d'Alpuget, oral history interview with the author, Sydney, 21 February 2020.

57 Bob Hawke, The Hawke Memoirs (Port Melbourne: William Heinemann Australia, 1994), xi.

58 Blanche d'Alpuget, oral history interview with the author, Sydney, 21 February 2020.

59 Hawke, The Hawke Memoirs, xi.

60 Hawke, The Hawke Memoirs, xi.

61 Bob Hawke Prime Ministerial Library, Bob Hawke Collection, Papers, Hawke Memoirs, Draft of Hawke's Speech at the Launch of The Hawke Memoirs, 16 August 1994, RH45/2.

62 Hawke, The Hawke Memoirs, xv. 
The text recounts key episodes in Hawke's early years, such as his brother's death and his own motorcycle accident, both of which convinced his family that he was 'destined for a special life'. ${ }^{63}$ Hawke outlines his higher education journey and his rise to the ACTU presidency, and goes on to justify his stalking of Hayden by noting that there were 'polls regularly showing me as preferred leader of the party'. ${ }^{64}$ Though proud of his record-breaking capacity to drink as a younger man, he makes a very brief acknowledgement that he 'behaved badly in drink', hence the pledge of sobriety in $1980 .{ }^{65} \mathrm{He}$ crystallises the secret to his 1983 electoral victory in breathtakingly reductionist terms: 'The simple fact is that I like people.' ${ }^{\prime 6}$ His early Cabinet is dubbed 'the best' since 1901, and he is careful to remind his reader that this was 'the Hawke Government, not the HawkeKeating Government', lest anyone be in any doubt about who was in charge. ${ }^{67}$ Extensive space is dedicated to Hawke's interest in Indigenous political causes, arguably to conceal his government's failure to legislate either national land rights or a treaty with the First Australians. ${ }^{68}$ Hawke's greater policy achievements are outlined, such as the Prices and Incomes Accord; the floating of the dollar and other financial deregulation; the successes in environmental policy; the foreign policy initiatives, especially concerning the sanctions against South African apartheid; and the antimining Antarctic Treaty.

The critical reviews heavily publicised two major defects in the book: Hawke's egocentric approach to history and his obsession with reducing the reputation of Paul Keating, who was treasurer throughout Hawke's prime ministership. On the latter point, it is revealing that there are more entries associated with Keating than with Hawke himself in the index of the book. ${ }^{69}$ Michelle Grattan declared that too much of Hawke's narrative was aimed at 'portraying Paul as a bastard'. ${ }^{70}$ James Walter, a political

63 Hawke, The Hawke Memoirs, 14.

64 Hawke, The Hawke Memoirs, 97.

65 Hawke, The Hawke Memoirs, 28, 103.

66 Hawke, The Hawke Memoirs, 136.

67 Hawke, The Hawke Memoirs, 156, 159.

68 Hawke includes a four-page appendix listing his achievements in the field of Indigenous affairs, Hawke, The Hawke Memoirs, 590-93. Criticism of Hawke's vacillations on land rights and treaty are offered in Stuart Macintyre, A Concise History of Australia, 4th ed. (Port Melbourne: Cambridge University Press, 2016 [1999]), 277; Frank Bongiorno, The Eighties: The Decade that Transformed Australia (Carlton: Black Inc., 2017 [2015]), 77-78, 250.

69 Hawke, The Hawke Memoirs, 612-13.

70 Michelle Grattan, 'Bob Hawke: No Warts and All', Canberra Times, 17 August 1994, 13. 
psychologist, accused Hawke of 'fantastic egotism'. ${ }^{71}$ On the egocentric properties of the narrative, one contemporary reviewer's interview with Hawke seemed revealing. Asked by Sebastian Faulks if it was acceptable for a 'dinky-di bloke' to 'bang his own drum' to this extent, Hawke replied, 'where there's something to be genuinely modest about, then you should be modest; but if you've got things done then you should be proud of it' ${ }^{72}$

It is striking that many Labor Party stalwarts sharply rebuked the former prime minister for his book. ALP President Barry Jones noted that 'there was disappointment and regret within the party about the book'; backbench MP Wayne Swan said that Hawke's vituperative claims 'did not go down well with the troops' ${ }^{73}$ Hawke sold 75,000 copies of the book, a figure highly acclaimed among the publishing community, yet much of the public rejected the book. A Newspoll survey in August 1994 found that an outright majority of responders approved of Hawke publishing his record, but just 31 per cent approved of what he actually included, compared with a 37 per cent disapproval score. ${ }^{74}$ Few begrudged Hawke's right to publish, but readers and critics clearly rejected the score-settling pockets of the narrative.

These figures make greater sense in the context of two particularly explosive claims contained in the book, both of which relate to Keating. The first was remarkably targeted, and has echoed through other texts such as the Hawke telemovie: Hawke asserted that, in a heated argument with Keating in January 1991, the latter had described Australia as 'the arseend of the world'. ${ }^{75}$ This claim and the ensuing press coverage did nothing to lift Keating's public standing as prime minister. A Newspoll conducted in the wake of the revelation indicated that 52 per cent of respondents believed Hawke's claim, while just 13 per cent felt that Keating's denial was honest. ${ }^{76}$ Even d'Alpuget felt that the book would have been better without this quotation. ${ }^{77}$ More explosive, however, was Hawke's claim

71 James Walter, 'The Transformations of Mateship: Autobiography and Politics', Voices: The Quarterly Journal of the National Library of Australia 5, no. 3 (1995): 111.

72 Hawke quoted in Sebastian Faulks, 'Unexpurgated Blokelore', Guardian, 3 September 1994, 25.

73 Keith Scott, 'Mates Back off 'Bitter, Sad' Hawke', Canberra Times, 16 August 1994, 1; Norman Abjorensen, 'Making Sure History Is Writ in Your Favour', Canberra Times, 25 June 1994, 16.

74 Newspoll survey conducted 19-21 August 1994, accessed 4 July 2019, bit.ly/33e2e4E (site discontinued).

75 Keating quoted in Hawke, The Hawke Memoirs, 501.

76 Newspoll survey conducted 24-26 June 1994, accessed 4 July 2019, bit.ly/31p5qIZ (site discontinued).

77 Blanche d'Alpuget, oral history interview with the author, Sydney, 21 February 2020. 
that Keating had initially opposed the Hawke government's decision to join the United Nations-sanctioned First Gulf War against Saddam Hussein's invasion of Kuwait in late 1990. Hawke claimed that Keating had remarked: 'What has the US ever done for us?'78 Keating sprang to action, describing the allegation as 'a straight lie, a straight distortion'. ${ }^{79}$ The Opposition, however, saw Hawke's allegation as an opportunity to score a serious political hit on Keating. Liberal leader Alexander Downer and National Party leader Tim Fischer moved to suspend the standing orders of the House during question time that day in order to berate Keating. ${ }^{80}$ The issue remained alive until former Senate leader John Button made a personal statement taking ownership of the remark, which seemed to have its inspiration in a joke about the Roman Empire in the Monty Python film The Life of Brian, thereby defusing Hawke's political bomb. ${ }^{81}$ Hugh White, the collaborator responsible for drafting most of Hawke's Gulf War chapter, acknowledged his likely error in an oral history interview: 'I am now persuaded that I got it wrong, and that it was in fact Button who said that. ${ }^{82}$ Both of the punishing anecdotes published by Hawke landed their blows, though ultimately the prime minister in exile hardly re-enamoured himself with the electorate at large.

The 1990s were clearly a reactive phase in historiographical terms for Hawke; however, they need not have been. The response to another publication about Hawke reveals that there was a market ready for an honest and dignified treatment of Hawke's achievements. Prior to both The Hawke Memoirs and Labor in Power, former speechwriter Stephen Mills published The Hawke Years: The Story from the Inside. Launched in mid-1993, the book was judged by one of Australia's leading historians as 'an informative account', and made it to the top 10 list of recommended reads in at least one metropolitan newspaper. ${ }^{83}$ In a couple of published extracts, Mills deployed particularly heroic scenes of Hawke at his best, one in which he 'set out to prevent the war' in the Gulf in 1991, and another involving the final weeks of Hawke's leadership and his 'departure

78 Keating quoted in Hawke, The Hawke Memoirs, 517.

79 Keating quoted in Ian McPhedran and Ross Peake, 'Weak Hawke Lied: Keating', Canberra Times, 12 October 1994, 1.

80 Cth. House of Representatives, Parliamentary Debates, 12 October 1994, 1801, 1805.

81 Ross Peake, 'Fiery Keating Has Button Admitting it Was Him Flying a Rhetorical Kite', Canberra Times, 14 October 1994, 3.

82 Hugh White, interview with the author, The Australian National University, Canberra, 14 November 2019.

83 Stuart Macintyre, 'Prime Minister and the Dragon', Age, 19 June 1993, 8; 'Top Shelf', Sunday Age, 27 June 1993, 9. 
of enduring dignity' ${ }^{84}$ It is worth noting that Hawke was given the opportunity to vet this book before publication. ${ }^{85}$ At a breakfast for the Evatt Foundation in early August 1993, Mills and Phillip Chubb publicly discussed the legacy of the Hawke years, and the Sydney Morning Herald interpreted the positive tenor of their discussion to represent 'something of a comeback' for the former prime minister's reputation. ${ }^{86}$

The memoirs, however, firmly scotched that prospect. Reacting to the outrage with which his book was received, Hawke gave a launch speech at the National Press Club on 17 August 1994. The speech was embittered and agitated, the orator repeatedly thumping the lectern like the union leader of old. Hawke hectored the assembled media for overemphasising the Keating dimension of his book, and attacked the 'precious selfappointed guardians of proper behaviour in the Labor Party' for their attacks. ${ }^{87}$ As public reaction to the $\mathrm{ABC}$ series and the Memoirs continued to roll on, it became clear that a reputational 'comeback' was not destined for Hawke in the mid-1990s. In deliberate pursuit of vindication, Hawke ultimately starved himself of the adulation that he still craved.

\section{The Ascendant Phase, 2010-19}

In the first decade of the new millennium, Hawke allowed his political career to recede into history while he continued pursuing a host of other interests in the arenas of business and foreign affairs. By 2010 the professional years of Hawke's life were drawing to a close. D'Alpuget recorded that, as her husband turned 80 , he 'hit his third hole-in-one, snorkelled for the first time, went swimming with dolphins ... and learned to waltz. ${ }^{88}$ This retirement period afforded Hawke much time to think, reflect and facilitate efforts to curate his reputation for posterity. Notwithstanding some periodic bouts of illness, Hawke involved himself actively in the last decade of his life in the pursuit of a mythology that is

84 Extract from The Hawke Years published as 'Bridging the Gulf', Canberra Times, 22 May 1993, 3; Extract from The Hawke Years published as 'Hawke-The End of the Affair', Age, 22 May 1993, 4. 85 Hawke's margin comments on the manuscript are contained in the Bob Hawke Prime Ministerial Library, Bob Hawke Collection, Papers, Hawke Memoirs, Draft Manuscript of Stephen Mills, The Hawke Years, RH45/17.

86 Tony Stephens, 'Hawke Back in Heroes' Battle', Sydney Morning Herald, 12 August 1993, 4.

87 Bob Hawke, Speech to the National Press Club Luncheon [Series 94, Episode 25], 17 August 1994, NAA: C475/1718262.

88 Blanche d'Alpuget, Hawke: The Prime Minister (Carlton: Melbourne University Publishing, 2010), 371 . 
now deeply and firmly entrenched in public consciousness. He remained relevant as a public figure, and a sense of Hawke nostalgia emerged in representations of him in this period, increasing over time. Even in this phase, however, the Hawke-d'Alpuget legacy-building process was not without controversy.

The ascendant phase began with a shaky start. Building on her earlier successful biography of Hawke, d'Alpuget in 2010 produced a second volume entitled Hawke: The Prime Minister. When first approached by Louise Adler of Melbourne University Press (MUP) to write the book, d'Alpuget confessed to some concern about the likely pressure of the project; nonetheless, she agreed to produce the book with MUP. ${ }^{89}$ The book was highly adulatory, and was launched by Prime Minister Julia Gillard, who declared that Hawke was 'a model for all of us'. ${ }^{90}$ Notwithstanding this auspicious start to the life of the book, its publication proved disruptive in a number of ways. First, it received a public thrashing from Hawke's own daughter, Sue Pieters-Hawke, who said:

Personally, I think that glib observations of character and events, or the ill-informed and tawdry dwelling on deeply personal dimensions of a family's life, demean public conversation, political commentary, and the people who indulge in them. ${ }^{91}$

This remark led to some tense exchanges and even a physical altercation between Blanche and Sue. ${ }^{92}$ Second, the book reopened Hawke's feud with Keating, who swiftly sent an open letter to the Australian, in which he wrote, 'yours and Blanche's rewriting of history is not only unreasonable and unfair ... it is grasping. ${ }^{93}$ The reopening of the old feud was the subject of much commentary for several days, and the consensus appeared to be that both former leaders were simply 'brutal, forceful and endlessly creative' in their mutual antagonism. ${ }^{94}$

89 Blanche d'Alpuget, oral history interview with the author, Sydney, 21 February 2020.

90 Julia Gillard quoted in 'Gillard Praises “Role Model” Hawke at Book Launch', ABC News, 13 July 2010, accessed 23 July 2019, ab.co/2Tcolnn.

91 Sue Pieters-Hawke quoted in Nick Ralston, 'If Only Hazel Could Speak for Herself', Sydney Morning Herald, 17 July 2010, 1.

92 Annette Sharp, 'How Bob-Blanche Book Saga led to 5-star Air Lounge Spat: Inside Hawke Family Feud', Sunday Mail, 3 July 2011, 34. D'Alpuget confirms that this happened in Hawke and Rielly, Wednesdays with Bob, 265.

93 Keating, 'Keating Hits Back: "Hawke Only Survived as PM with My Help"', Australian, 15 July 2010, 2.

94 Tom Dusevic, 'Resumption of Hostilities', Australian, 15 July 2010, 13. 
With many of the wounds in the public and private spheres of Hawke's life now open for all to see, the media were left to reflect on the historiographical merit of the biography. The Sydney Morning Herald described the brawl 'an unedifying scrap'; the Age mused that 'neither man has a monopoly on bitterness'; Ross Fitzgerald, however, described the book as 'extremely insightful'. ${ }^{55}$ The most scathing criticism came later from Gareth Evans, a senior minister in both the Hawke and Keating governments, who described the book as 'a work of second-rate hagiography'. ${ }^{96}$ In the face of these critiques, d'Alpuget remained steadfast in her account: 'Hawke's brilliant political career is over but the long tail of its comet still shines. ${ }^{97}$ It must be said that the book included some valuable material for the historic record. For one thing, it offered a window into the collaborative way that Hawke's private office as prime minister functioned..$^{98}$ For another, it reflected critically on his sexual behaviour as prime minister, which included the resumption of his relationship with d'Alpuget in the late 1980 s. ${ }^{99}$ However, the author's proximity prompted scepticism: with Hawke beside her, d'Alpuget was questioned about how a wife could write an 'objective' account. Thus, the book was clearly designed to be another brick in an already expanding Hawke nostalgia wall.

Even as Hawke: The Prime Minister was creating headlines, another influential cultural product was being unleashed upon the Australian audience. On 18 July, just days after the launch of d'Alpuget's book, Channel 10 broadcast the widely anticipated Hawke telemovie, starring Richard Roxburgh as the leading man. An impressive audience of 1.6 million Australians tuned in to watch the show, far outstripping the sales units of any book ever written about Hawke and the earlier television audience for Labor in Power. ${ }^{100}$ Though accounting for his extramarital affair with d'Alpuget and his earlier alcoholism, the film to some extent idolised the Hawke years, even concluding with a list of the

95 'What They're Saying ... about the Bob Hawke Biography', Sydney Morning Herald, 18 July 2010, 22; Ross FitzGerald, 'Portrait of a Folk Hero', Sydney Morning Herald, 7 August 2010, 32.

96 Gareth Evans quoted in Hawke and Rielly, Wednesdays with Bob, 145.

97 d'Alpuget, Hawke: The Prime Minister, ix.

98 d'Alpuget, Hawke: The Prime Minister, 67-76.

99 d'Alpuget, Hawke: The Prime Minister. For discussion about Hawke's infidelities as prime minister, see page 232. For discussion on the relationship with private secretary Jean Sinclair, see pages 338-39. In her later commemorative edition, d'Alpuget subtly suggested that Hawke had even been unfaithful during his marriage to her, remarking that their wedding vows spoke to 'a spiritual union rather than a fleshly one'. See Blanche d'Alpuget, Bob Hawke: The Complete Biography (Cammeray: Simon \& Schuster, 2019), 915.

100 '1.6m Watch Hawke Movie’, Northern Territory News, 20 July 2010, 16. 
Hawke government's achievements. Once again, a heroic Hawke was directly contrasted with a highly villainous Keating (Felix Williamson), whose dialogue included the infamous 'arse-end of the world' remark. ${ }^{101}$ Hawke and d'Alpuget agreed to cooperate with producer Richard Keddie in the pre-production phase. ${ }^{102}$ Channel 10 's success was complemented by an interview with Hawke and d'Alpuget that aired immediately after the telemovie, and reportedly more than 800,000 viewers 'hung around to watch "Hawke: The Interview". ${ }^{103}$ The response was not uniformly positive, of course; one reviewer in the Herald Sun pointed out that the film 'does not capture the character or importance of Hazel Hawke'. ${ }^{104}$ Further, Hawke and d'Alpuget were themselves surprised by the somewhat 'salacious' nature of the final product. ${ }^{105}$ Nevertheless, there was clearly a receptive audience awaiting the telemovie, which reportedly outstripped the plethora of crime shows airing simultaneously and hooked 60 per cent of the 16-54 age demographic. ${ }^{106}$ Screened less than a month after the ousting of Rudd, this film arguably fed an audience that was increasingly both cynical and nostalgic.

In the three years immediately before Hawke's death, two textual products were particularly powerful in their effort to cement his legendary politicocultural status. Importantly, both were contributed to and authorised by Hawke and his supporting cast. The first was a two-part documentary entitled Hawke: The Larrikin \& The Leader (2018) directed by Bruce Permezel and aired on the ABC. Hawke and d'Alpuget contributed directly to the project, and private secretary Jill Saunders was personally acknowledged by the creators, as was the Hawke Prime Ministerial Library in South Australia. ${ }^{107}$ Similarly, Derek Rielly's high-profile publication Wednesdays with Bob (2017) depended on the approval of Hawke and d'Alpuget, as well as Saunders's organisational cooperation; Blanche is quoted as saying to the journalist, 'you'll have to get it past his office manager!' ${ }^{108}$ A point worth noting is that the list of interviewees is remarkably similar across both projects: wife and biographer Blanche,

101 Hawke, directed by Emma Freeman (Victoria: The Film Company, 2010).

102 Darren Devlyn, 'Hawke-The Movie', Sunday Mail, 16 August 2009, 10.

103 '1.6m Watch Hawke Movie'.

104 'What They're Saying', 22.

105 Blanche d'Alpuget, oral history interview with the author, Sydney, 21 February 2020.

106 'Hawke Movie Smashes the Opposition', Herald Sun, 20 July 2010, 12.

107 Credit listing found at ABC, 'Hawke: The Larrikin and the Leader', ABC.net, 2019, accessed

7 July 2019, www.abc.net.au/tv/programs/hawke-the-larrikin-and-the-leader/.

108 d'Alpuget quoted in Hawke and Rielly, Wednesdays with Bob, 12. 
Cabinet colleagues Gareth Evans (possibly forgiven for his comments on the 2010 biography) and Kim Beazley, and former sparring partner John Howard. For the book, Rielly also engaged with close friends of Hawke such as Richard Woolcott, John Singleton and Col Cunningham, alongside long-time Hawke ally and former staffer Ross Garnaut. For the biopic, an even larger collection of followers was gathered: Kelty and Greg Combet from the ACTU; former minister Susan Ryan; former Hawke staffers Craig Emerson, Bob Hogg and Dennis Richardson; and onetime factional ally Graham Richardson. Though hardly surprising, the common interviewee lists indicate the collective and organised nature of the legacy-building mission.

The narrative framing of the ABC bio-documentary was mostly full of praise, designed for a nostalgic audience. Roxburgh's narration began the biopic with an appeal to populist nostalgic sentiment: 'Australians have never been so distrusting of politicians, but there was a time when things were different.' ${ }^{109}$ Frank Bongiorno, in reviewing the series, remarked that it was 'rather generous'. ${ }^{10}$ The stand-out sound bites are typical of the conventional Hawke mythology: 'Bob was always a leader' (Kelty), 'he really liked ordinary people and being with them' (Richardson), 'he worked very well with the people immediately around him' (Howard) and 'conviction overrode polls, and that's the missing ingredient today' (Rod Cameron). ${ }^{111}$ Both episodes of the biopic opened with iconic Australian anthem 'The Boys Light Up', and the narrator's contributions helped thread together a narrative intended to idealise Hawke's character; the introduction to the first part described him as 'one of us', while the second part concluded with Hawke's betrothal to Blanche and the cliché of him returning from political heights to 'being part of the mob'. ${ }^{12}$ The lexis was not unlike that heard at Hawke's funeral, intended chiefly to support and sustain the Hawke cult of personality among the viewing public.

109 Hawke: The Larrikin and the Leader, episode I, directed by Bruce Permezel (Australian Broadcasting Corporation, 2019).

110 Frank Bongiorno, 'The Larrikin as Leader: How Bob Hawke Came to be One of the Best (and Luckiest) Prime Ministers', Conversation, 9 February 2019, accessed 4 December 2019, theconversation.com/the-larrikin-as-leader-how-bob-hawke-came-to-be-one-of-the-best-and-luckiestprime-ministers-91152.

111 Hawke: The Larrikin and the Leader, episodes I and II.

112 Roxburgh quoted in Hawke: The Larrikin and the Leader, episodes I and II. 
Scattered through this documentary were veiled snippets of a more critical commentary, one that has been somewhat concealed in the public consciousness in recent years. Two quotations, in particular, should have given greater cause for reflection. The first came from Richardson, a factional kingmaker who backed Hawke and then Keating before backing out of parliament himself amid considerable scandal. Reflecting on Hawke's pre-prime ministerial follies, Richardson said: 'He did some appalling things when drunk ... Let's face it: a Bob Hawke today, behaving in the same manner, would never become prime minister.' ${ }^{113}$ While the statement might reflect something of the uneasiness between Hawke and a man who did more than most to bring his career undone, Richardson's remark also points to the more forgiving political context in which Hawke operated. The comment demonstrates an awareness of context that has the capacity to demythologise the Hawke persona and remind overawed viewers that Hawke's rise to power defies contemporary sensibilities towards civic expectations of politicians. The second comes from Neal Blewett, Hawke's minister for health, who effectively called out Hawke's much neglected impact on Labor's parliamentary culture during his campaign to replace Hayden:

I think that was a point at which the morality of the Labor Party was undermined, and I think that the philosophy which lay behind Hawke's decision - whatever it takes to win-triumphed at that point, and in a way the Labor Party has suffered from that decay in its morality ever since. ${ }^{114}$

The implications of Blewett's comment are quite severe. If we accept his assessment, then we see the actions of Hawke in 1983 as prefiguring as well as influencing those of Keating in June and December 1991, Beazley in 2003, Rudd in 2006 and 2013, and Gillard in 2010. That is to say, Hawke's trajectory to the top pioneered and legitimised the undermining of a serving leader that has characterised most leadership transitions within the Labor Party since then. One can hardly imagine any prime minister, let alone Hawke, rushing forth to claim this as their legacy. None of this, of course, dominated the media discourse about Hawke as the documentary aired; the tone of coverage was as nostalgic as the biopic itself. Troy Bramston, writing in the Australian, said: 'It is a pity there is

113 Richardson quoted in Hawke: The Larrikin and the Leader, episode I.

114 Blewett quoted in Hawke: The Larrikin and the Leader, episode II. 
no Hawke in politics today, or on the horizon.' ${ }^{115}$ Amid this framing, neither Richardson nor Blewett are likely to shift the gravity of the Hawke legacy on this point.

Derek Rielly's unique project Wednesdays with Bob, in which the subject was credited as co-author, was equally predicated on a desire to pay homage to Hawke and his government. D'Alpuget and Saunders were explicitly acknowledged for approving the project, and credit was given to the likes of Beazley, Evans and Garnaut for their enthusiastic participation. ${ }^{116}$ Equally important were the reviewers and journalists who helped popularise the unorthodox publication. Wednesdays with Bob was the subject of a major piece for the Australian by Trent Dalton, which was followed by the publication of an extract about Hawke and d'Alpuget's complex relationship in the Daily Telegraph. ${ }^{117}$ A number of favourable reviews were published following the launch of the book, and several papers listed it among their top recommendations. ${ }^{118}$ That said, not every review was adulatory. The publisher Richard Walsh, writing in Australian Book Review, was backhanded in his compliments when he was not just scathing:

Rielly has served up a curate's egg as some kind of dog's breakfast. But, for Hawkophiles, it will be a must read. For others, there may well be enough gems sprinkled throughout to make the hagiography tolerable. ${ }^{119}$

Nevertheless, the book reportedly 'recorded high sales' throughout 2018, while other political reads by Jacqui Lambie and Barnaby Joyce languished on the shelves. ${ }^{120}$

115 Troy Bramston, 'Oh, for a Hawke in Canberra Now', Australian, 6 February 2018, 12.

116 Hawke and Rielly, Wednesdays with Bob, 289.

117 Trent Dalton, 'Hawke's One and Only Weakness', Weekend Australian, 17 November 2017; Derek Rielly, 'For the Love of Bob', Daily Telegraph, 18 November 2017, 34.

118 See, for example, Troy Bramston, 'Silver Bodgie Still Refuses to Hold Back', Australian, 9 December 2017, 22; Jenny Wheeler, 'Review of Wednesdays with Bob', North \& South, no. 385, April 2018; 'Top Ten Biographies', Sunday Age, 11 February 2018; Patrick Durkin, 'The 3 Best Leadership Books for 2018', Australian Financial Review, 2 January 2018, 8; Stephen Jeffrey, 'In Short Non-Fiction: Pick of the Week', Canberra Times, 20 January 2018, 17.

119 Richard Walsh, 'Richard Walsh Reviews 'Wednesdays with Bob' by Bob Hawke and Derek Rielly', Australian Book Review, no. 397, December 2017, accessed 19 July 2019, bit.ly/2Tcg5nG. 120 Natassia Chrysanthos, "Crazy” Growth for Self-Help Books in 2018', Sydney Morning Herald, 23 December 2018, 22. 
Rielly's work - that of a journalist-is written in prose that is crisp enough to engage a wide audience, but it shares the same core weaknesses as the $\mathrm{ABC}$ biopic; that is to say, the Hawke legend is rarely nuanced and, where it is, the audience is quite clearly positioned to endorse its glowing account of Hawke's legacy and to have their detestation of their current representatives confirmed. The author is prudently clear about his purpose:

I tell Hawke that I hope these interviews will lasso his legacy and, by virtue of what I presume is still the sparkling intellect I witnessed growing up, demonstrate the drudgery of modern politics. ${ }^{121}$

The entire narrative is subordinated to that overarching goal. From the outset, Hawke is described as Australia's 'greatest living politician' who had 'a connection to the Australian people that was never severed over four elections'. ${ }^{122}$ A concise list of the Hawke government's achievements is proffered, including 'four election victories'; 'the floating of the dollar' and 'deregulation of the financial system'; the Labor-ACTU Accord, which developed a limited partnership between employers and the union movement; 'reinventing Medibank as Medicare'; 'saving Antarctica from mining for fifty years'; saving the Franklin River from damming; 'compulsory superannuation'; a 40 per cent increase in secondary school retention rates; and a central role in the dismantling of apartheid. ${ }^{123}$ In turn, Rielly also acknowledges the recession over which Hawke presided, but does not question its causes at great length. ${ }^{124} \mathrm{He}$ unearths the occasional jarring note, such as Richard Woolcott's claim that the Antarctic Treaty to protect the ice continent from mining was inspired by electoral opportunism. ${ }^{125}$ But few of the other standard elements of the Hawke phenomenon are interrogated critically.

In personal terms, Walsh is perhaps right to describe this book as a work of hagiography in which the familiar tenets of the Hawke mythology are recycled. The well-versed (and not unreasonable) argument that Hawke was the best overseer of Cabinet government in Australia is proffered by Beazley, who describes Hawke's 'belief that he shone brighter when

121 Hawke and Rielly, Wednesdays with Bob, 18.

122 Hawke and Rielly, Wednesdays with Bob, 3-4.

123 Hawke and Rielly, Wednesdays with Bob, 21-22.

124 Hawke and Rielly, Wednesdays with Bob, 22, 236.

125 Woolcott quoted in Hawke and Rielly, Wednesdays with Bob, 48. 
other people shone with him'. ${ }^{126}$ Hawke's intelligent political style is deemed almost to transcend the trappings of the vocation itself. Asked about the Machiavellian nature of political leadership, Hawke dismisses any suggestion that he, either as trade unionist or prime minister, ever employed cunning strategies, or indeed blatantly lied. ${ }^{127}$ His history of alcoholism is effectively neutralised in Col Cunningham's euphemistic statement that 'when [Hawke] was drunk he was a bit different'. ${ }^{128}$ Hawke's extramarital affairs are also discussed somewhat leniently. The upshot of these approaches is that the book conveys an image of Hawke that is consistently idolatrous in its tone and much of its content.

More so than in the $\mathrm{ABC}$ biopic, the shadow of Keating falls across the narrative woven throughout Wednesdays with Bob. A number of quotations are included simply to contrast hero Hawke with villain Keating, not least of which is the written sound bite from Paul Kelly: 'Keating was a saboteur, pure and simple.' ${ }^{129}$ Hawke himself makes the contrast implicitly but clearly in his admission, 'I'm not a hater. ${ }^{130}$ Even former adversaries jump into the ring. Howard accurately describes the Hawke government's decision to float the Australian dollar in December 1983 as 'correct and courageous', though he is careful to write Keating out of that narrative. ${ }^{131}$ Garnaut pays tribute to Hawke for being able to advocate successfully on behalf of non-discriminatory immigration policies at a time of rapid economic change, but feels compelled to make the point that 'Paul couldn't have done it because Paul was a different personality. ${ }^{132}$ In Hawke's view, '[Keating is] such a hater. He just hates! And he just wants to claim a bit more than he's entitled to.' ${ }^{133}$ That statement in and of itself reflects a degree of possessiveness about the legacy of the reforms of the 1980s. For the critical reader, the book is highly consumable but its narrative must be read with scepticism. Beyond that readership, the intimacy and accessibility of the narrative will no doubt further enamour Hawke to an increasingly disillusioned and nostalgic body politic.

126 Beazley quoted in Hawke and Rielly, Wednesdays with Bob, 85.

127 Hawke quoted in Hawke and Rielly, Wednesdays with Bob, 98-99.

128 Cunningham quoted in Hawke and Rielly, Wednesdays with Bob, 211.

129 Kelly quoted in Hawke and Rielly, Wednesdays with Bob, 23.

130 Hawke quoted in Hawke and Rielly, Wednesdays with Bob, 34.

131 Howard quoted in Hawke and Rielly, Wednesdays with Bob, 183.

132 Garnaut quoted in Hawke and Rielly, Wednesdays with Bob, 243.

133 Hawke quoted in Hawke and Rielly, Wednesdays with Bob, 280. 
It is important that these narratives were supported by powerful accompanying images, many of which have been essential to the propagation of the 'Hawke legend'. Sean Scalmer has argued that modern politicians have been 'screened and groomed like the celebrities of film'. ${ }^{134}$ This was especially the case for Hawke, who carefully managed his pictorial and televisual screen performances. Consider, for instance, the iconic picture of Hawke celebrating Australia's victory in the America's Cup sailing contest in 1983; this image has been reproduced in The Hawke Memoirs, Hawke: The Prime Minister, Hawke (the movie) and elsewhere. Famous pictures of Hawke crying, including over his own daughter's drug affliction in 1984 and over the atrocities at Tiananmen Square in 1989, are incorporated in the Anson and d'Alpuget biographies, as well as in the ABC biopic. Video footage of the ageing Hawke sculling beers at cricket festivals served to capture the attention of younger audiences. Even the aforementioned February 1995 image of Hawke and d'Alpuget in their plush bathrobes was reconstructed ex post facto by the couple, who happily performed a recreation of the image in 2017 for 60 Minutes. ${ }^{135}$ With their empathetic power, images of Hawke actively serve the historiographical goals of those curating his legacy.

\section{Conclusion}

There have been successful and problematic attempts to shape and solidify the Hawke legacy over the past four decades. In print and on screen, the grand narratives that foster the Hawke legend-the 'larrikin' prime minister who loved ordinary people and who was prepared to overcome his own deep flaws for the good of the nation-have been successfully seared into the historical consciousness of the nation, and there they will likely endure. The Hawke government's record appears legendary, and the personal and political dimensions of Hawke's story are fundamentally

134 Sean Scalmer, 'The Rise of the Insider: Memoirs and Diaries in Recent Australian Political History', Australian Journal of Politics and History 56, no. 1 (2010): 103, doi.org/10.1111/j.14678497.2010.01543.x.

135 'Bob and Blanche Recreate their Famous "White Robe” Photo Shoot', Nine Entertainment Co., 60 Minutes, accessed 4 December 2019, www.9now.com.au/60-minutes/2017/clip-ciyi9n93x001n 0gp5sq20nzi0. 
intertwined in the public's adoration of him. Hawke himself remained politically relevant to the end of his life, starring in a series of Labor advertisements about Medicare in the 2016 election with great effect. ${ }^{136}$

At the end of Hawke's life, there were intimations of what could become a new phase in his legacy. At the ALP campaign launch in June 2016, he appeared alongside his old foe Keating in support of Bill Shorten's electoral gambit; in May 2019, just a week before his passing, Hawke drafted a joint statement with Keating to claim shared ownership of the economic reforms of the 1980s, making the bold declaration, 'the economy is Labor's'. ${ }^{137}$ Indeed, in her updated commemorative biography of Hawke published in late 2019, d'Alpuget wrote of the reignited 'bond of camaraderie' between the two former leaders. ${ }^{138}$ If a fourth phase of the Hawke legend is impending, it will surely be characterised by a sense of Hawke-Keating unity lacking in earlier treatments.

That said, Hawke's passing has also liberated those in his family to tell their stories with much greater freedom. The aforementioned Sue PietersHawke, already the author of two substantial books about her mother, moved swiftly to publish an edited collection of reminiscences about her father in late 2019. ${ }^{139}$ Importantly, these reflections were mostly as idealistic as Wednesdays with Bob; former Hawke media adviser Barrie Cassidy, for instance, writes, 'somehow I reckon Bob Hawke was never more popular than he was in his fading years. That's when people reflected on what once was, and may never be again. ${ }^{.140}$ These placid reminiscences have, to some extent, been offset by the bitter legal feud surrounding Hawke's estate. Indeed, controversial allegations raised by daughter Ros Dillon in relation to a sexual assault incident in the early 1980s involving a union official and Hawke ally could cause further historical debate about Hawke. ${ }^{141}$ It is for biographers-and the courts—-to test these allegations.

136 Pamela Williams, 'Federal Election 2016: How Labor's Mediscare Plot was Hatched', Australian, 4 July 2016.

137 Bob Hawke and Paul Keating, 'Scott Morrison is Flying in the Face of History with his Fallacious Claim', Sydney Morning Herald, 7 May 2019. For more on this, see Peter Hartcher, 'Bob Hawke and Paul Keating Reunite for the First Time in 28 Years to Endorse Labor's Economic Plan', Sydney Morning Herald, 7 May 2019.

138 d'Alpuget, Bob Hawke, 916.

139 Sue Pieters-Hawke with Hazel Flynn, Hazel's Journey: A Personal Experience of Alzheimer's (Sydney: Pan Macmillan, 2004); Sue Pieters-Hawke, Hazel: My Mother's Story (Sydney: Pan Macmillan, 2011); Sue Pieters-Hawke, ed., Remembering Bob (Sydney: Allen \& Unwin, 2019).

140 Barrie Cassidy in Pieters-Hawke, ed., Remembering Hawke, 155.

141 Bob Hawke as quoted by Ros Dillon, in Matt Bungard, 'Hawke Urged Daughter to Keep Rape Allegations Secret: Report', The Sydney Morning Herald, 7 December 2019. 
In forging his public mythology for 40 years, Hawke was greatly assisted by a loyal team of associates and supporters. D'Alpuget is owed much credit for her role in facilitating the love affair between Hawke and the Australian public through her biographies. Her stellar 1982 biography helped propel him towards the prime ministership in early 1983 and, with their marriage in 1995, her approval and contributions were provident in all projects thereafter. However, d'Alpuget's role should not prevent us from observing other loyalists involved in Hawke's biographical canon. Logistically, Saunders is widely recognised as the major gatekeeper to Hawke's reputational preservation and, by the 2010s, a familiar list of contributors was forming, with the likes of Beazley, Evans, Howard, Emerson, Garnaut and Kelty. Some are less surprising than others, but all are committed to particular components of the Hawke legend, and have been crucial in ensuring its success.

Further, the combination of written and filmed productions has ensured that Hawke's narrative was able to reach the largest possible audience. That audience, in turn, though briefly alienated in the 1990s, has increasingly favoured idolatry and nostalgic treatments of Hawke, contrary to the displeasure they feel towards the political generation succeeding him. This will no doubt have the effect of entrenching our deep sense of political nostalgia in the present, and will further blind us to the fact that the Hawke government grappled (and sometimes failed to grapple) with some of the socioeconomic dilemmas that continue to face Australia today, most notably the political plight of the First Australians. Additionally, Hawke's adeptness at packaging his biographical narrative for a public audience cannot be endlessly repeated, for Australians are increasingly wary of the life stories that their politicians display. At her husband's memorial, d'Alpuget spoke of a 'life triumphantly well lived'. In no small measure due to her, we may also speak of a life triumphantly well written. 
This text is taken from ANU Historical Journal II: Number 2, published 2020 by ANU Press, The Australian National University, Canberra, Australia.

doi.org/10.22459/ANUHJII.2020.05 